\title{
Supplemental Material: Poor performance of a common crevasse model at marine-terminating glaciers
}

Ellyn M. Enderlin ${ }^{1}$, Timothy C. Bartholomaus ${ }^{2}$

$5 \quad{ }^{1}$ Department of Geosciences, Boise State University, Boise, Idaho, 83725, USA
${ }^{2}$ Department of Geological Sciences, University of Idaho, Moscow, Idaho, 83844, USA
Correspondence to: Ellyn M. Enderlin (ellynenderlin@boisestate.edu) 


\section{Figures}
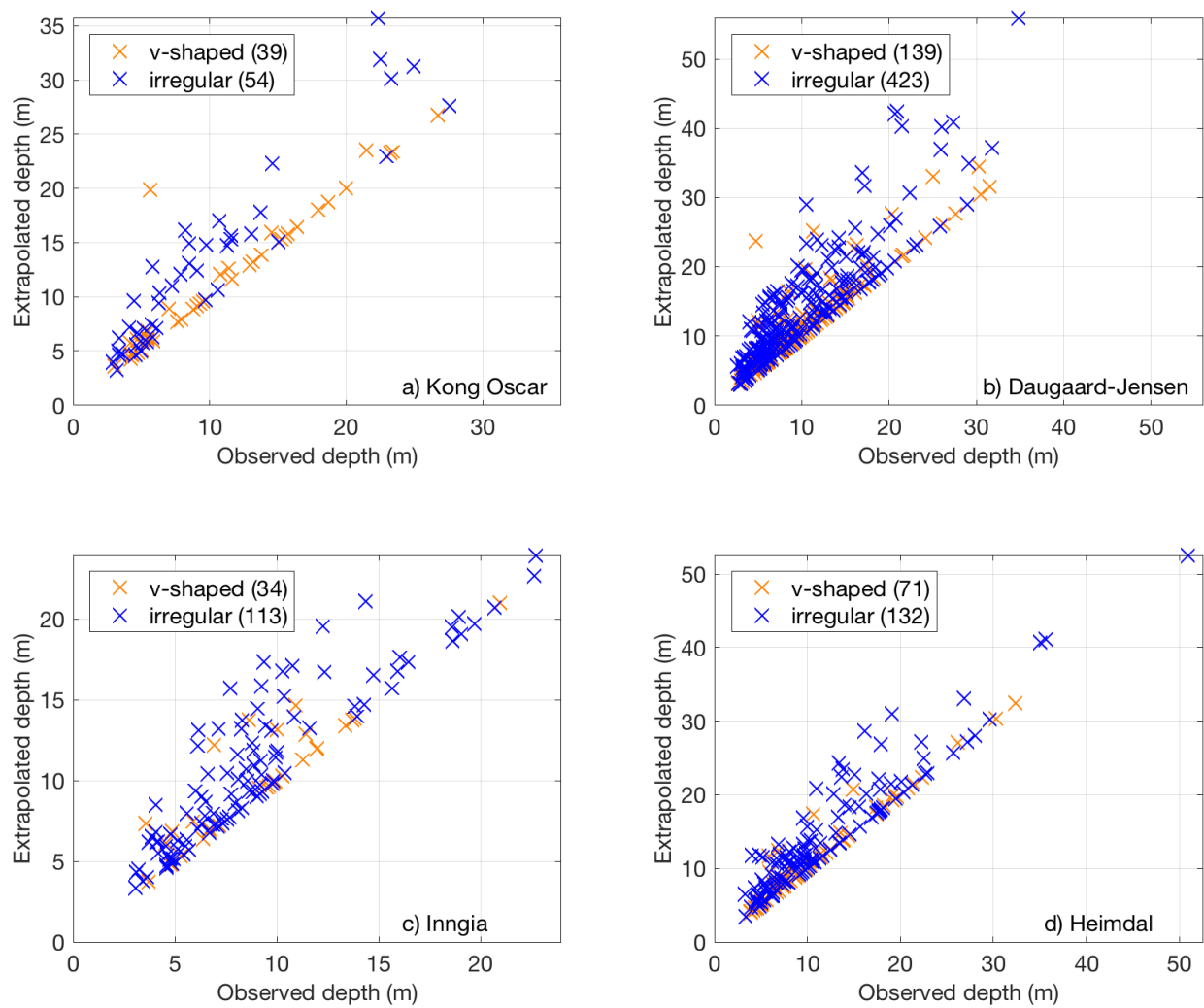

Figure S1: Crevasse depth estimates from surface elevation observations (observed depths) plotted against depth estimates using extrapolated using crevasse wall slopes (extrapolated depths). The number of each type of crevasse is listed in the legends. a) Data from Kong Oscar Gletsjer. b) Data from Daugaard-Jensen Gletsjer. c) Data from Inngia Isbræ. d) Data from Heimdal Gletsjer. 

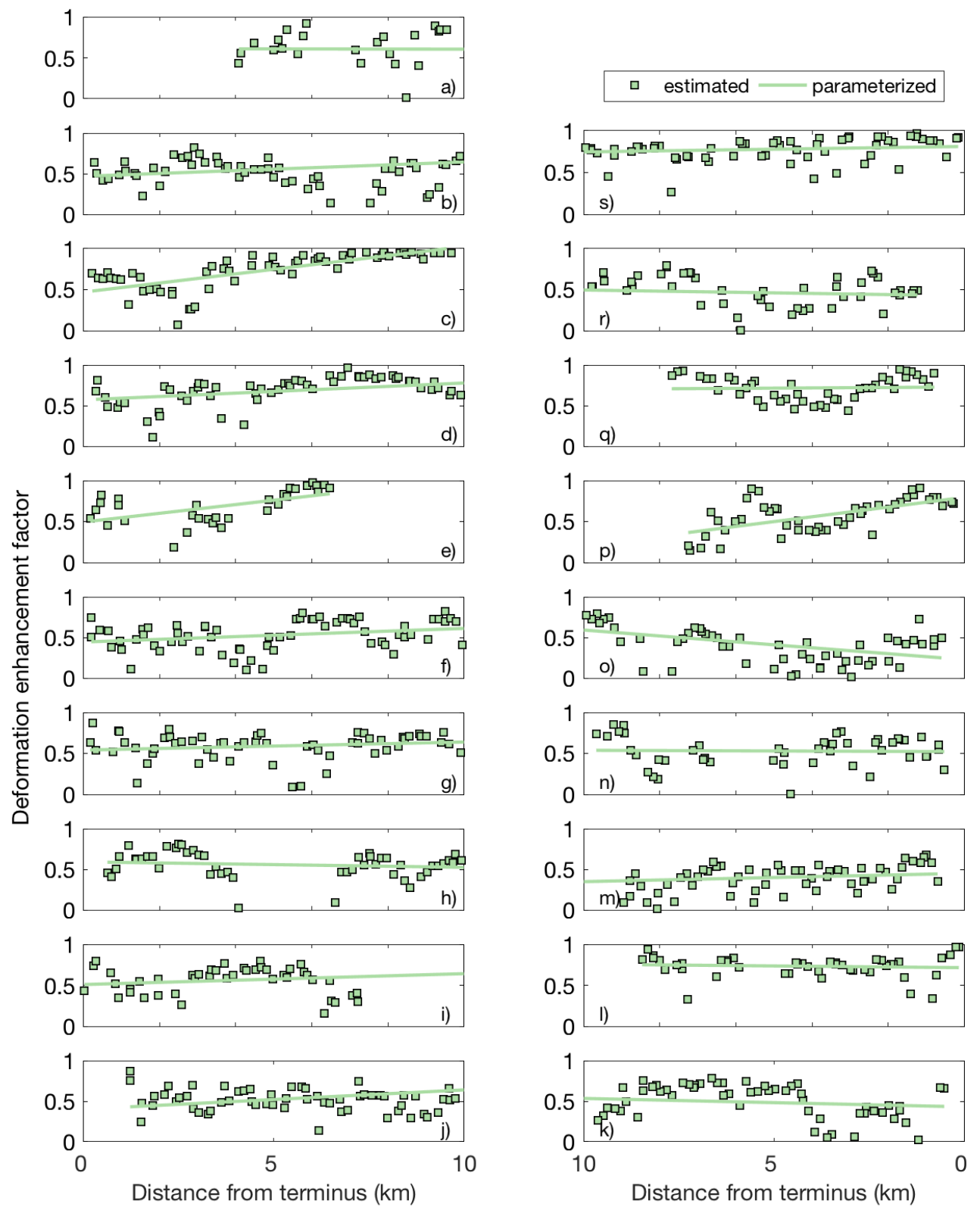

$\longleftarrow$ flow

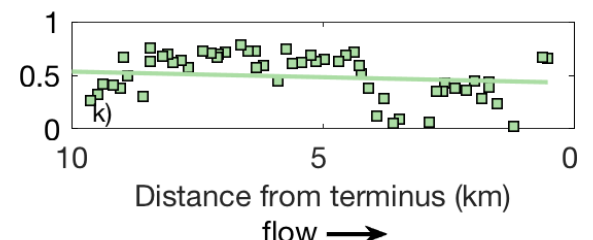

Figure S2: The deformation enhancement factor inferred from the misfit between observed crevasse depths and depths modeled plotted along flow. Panels are geographically arranged so that western glaciers are on the left and eastern glaciers are on the right. Common names

(Greenlandic names) are a) Ryder Gletsjer, b) Harald Moltke Bræ (Ullip Sermia), c) Kong Oscar Gletsjer (Nuussuup Sermia), d) Illiup Sermia, e) Upernavik North Isstrøm, f) Upernavik 
Isstrøm (Sermeq), g) Inngia Isbræ (Salliarutsip Sermia), h) Umiammakku Sermiat, i) Rink Isbræ (Kangilliup Sermia), j) Jakobshavn Isbræ (Sermeq Kujalleq), k) Heimdal Gletsjer, l) Koge Bugt Gletsjer, m) Helheim Gletsjer, n) Midgård Gletsjer, o) Kangerlussuaq Gletsjer, p) Dendrit Gletsjer, q) Magga Dan Gletsjer, r) Daugaard-Jensen Gletsjer, s) Zachariae Isstrøm. 

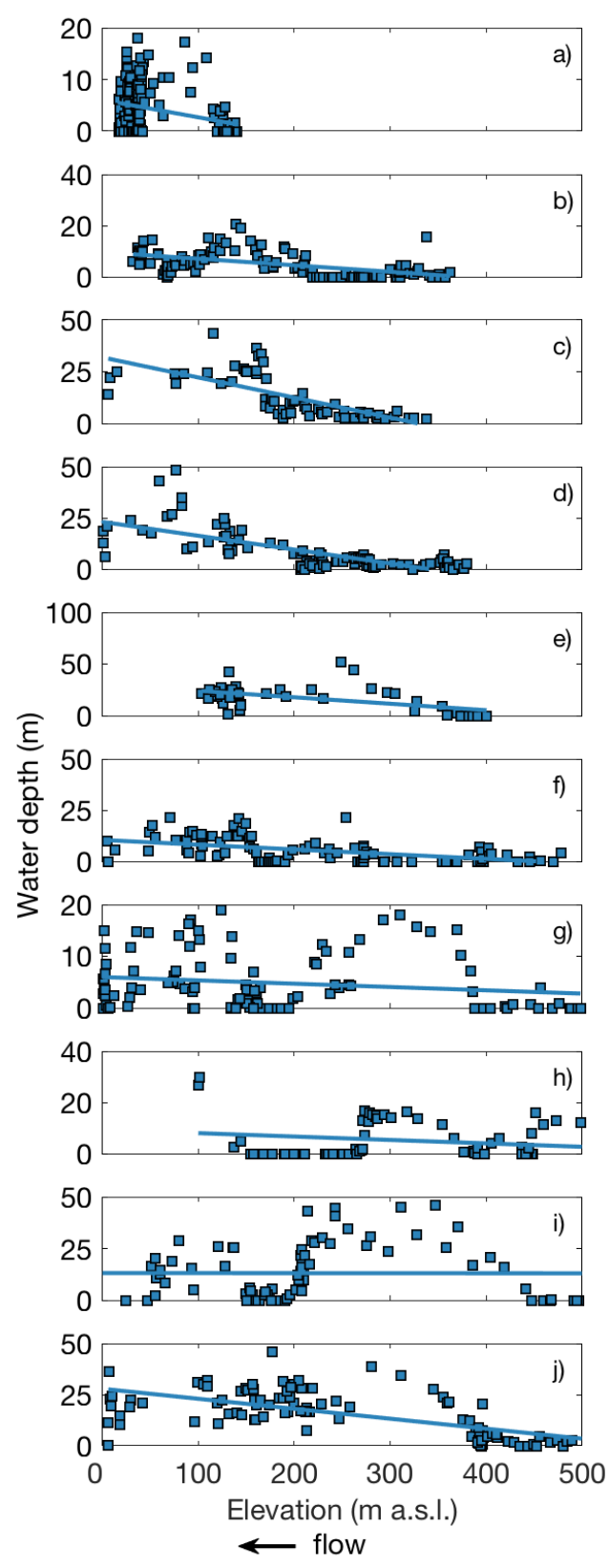

Figure S3: Water depths in crevasses inferred from the misfit between observed crevasse depths and depths modeled with a constant deformation enhancement factor plotted against surface elevation. Panels are organized geographically, as in Figure S2. 


$2011-2012-2013-2014-2015-2016-2017-2018$

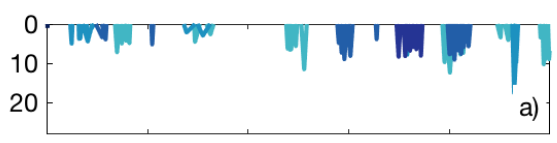

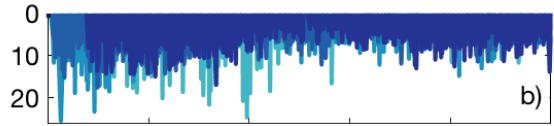
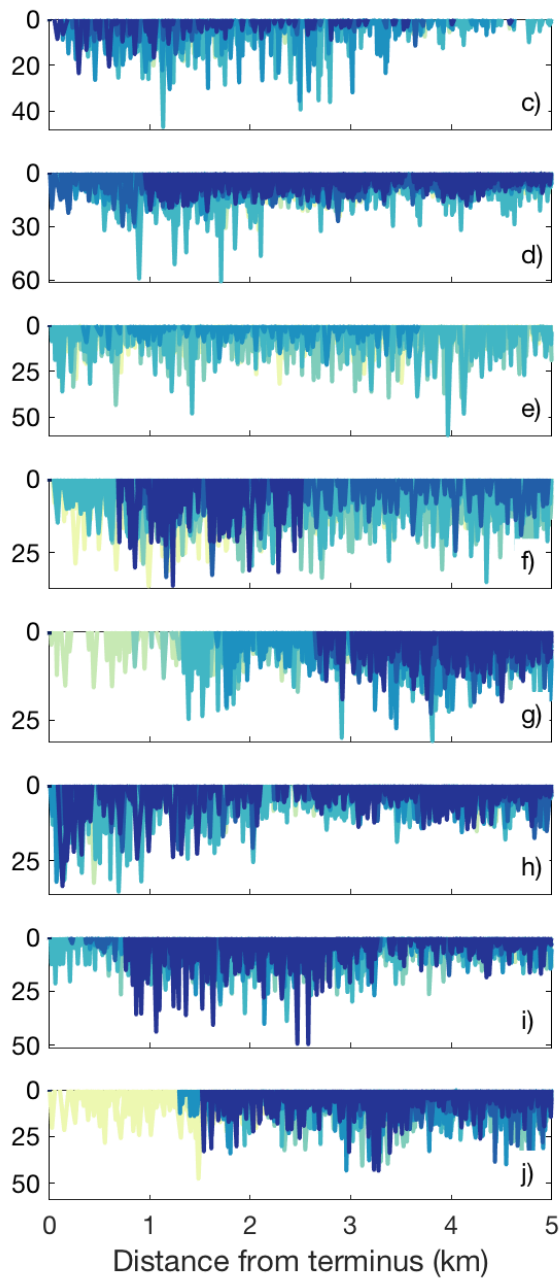

$\longleftarrow$ flow

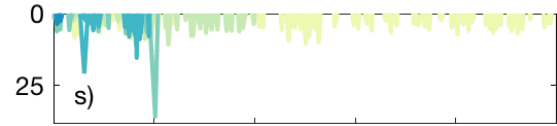

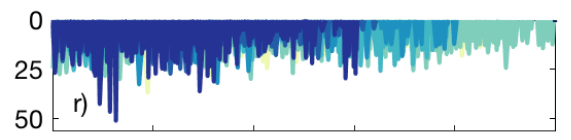
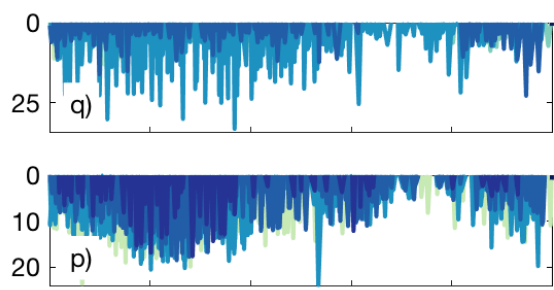

$25\left[\begin{array}{c}0 \\ 0 \\ 0\end{array}\right.$

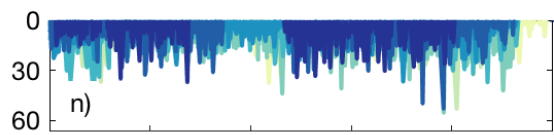

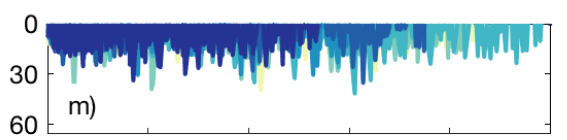
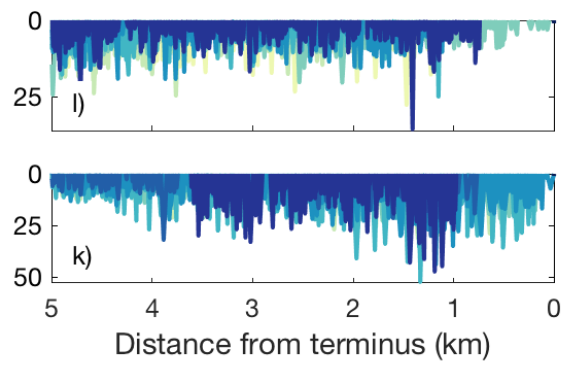

flow $\rightarrow$

Figure S4: Time series of observed crevasse depths over the seaward-most $5 \mathrm{~km}$ of each glacier. The colors correspond to the years listed in the legend. Panels are organized geographically, as in Figure S2. 

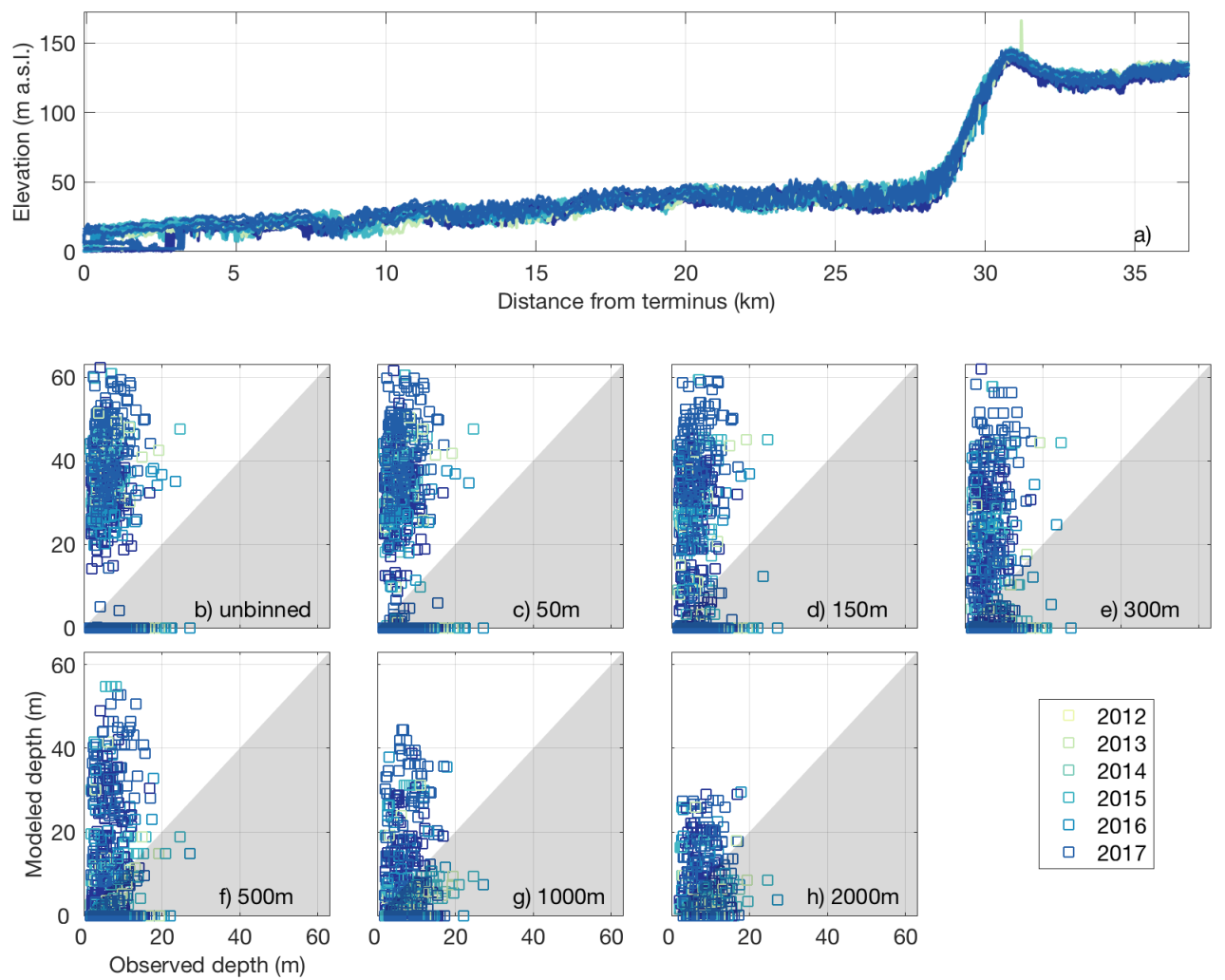

Figure S5: Ryder Gletsjer crevasse depth data. The legend indicates the observation year for all panels. a) Elevation profile time series extracted along the Operation IceBridge swath. b-h) Scatterplots of observed crevasse depths plotted against modeled crevasse depths. Points that fall in the white (gray) region represent model over-estimates (under-estimates) of the observed depths. All observations are shown in b whereas the maximum observed and median modeled depths within along-flow bins are shown in c-h, with bin sizes ranging from $50-2000 \mathrm{~m}$. 

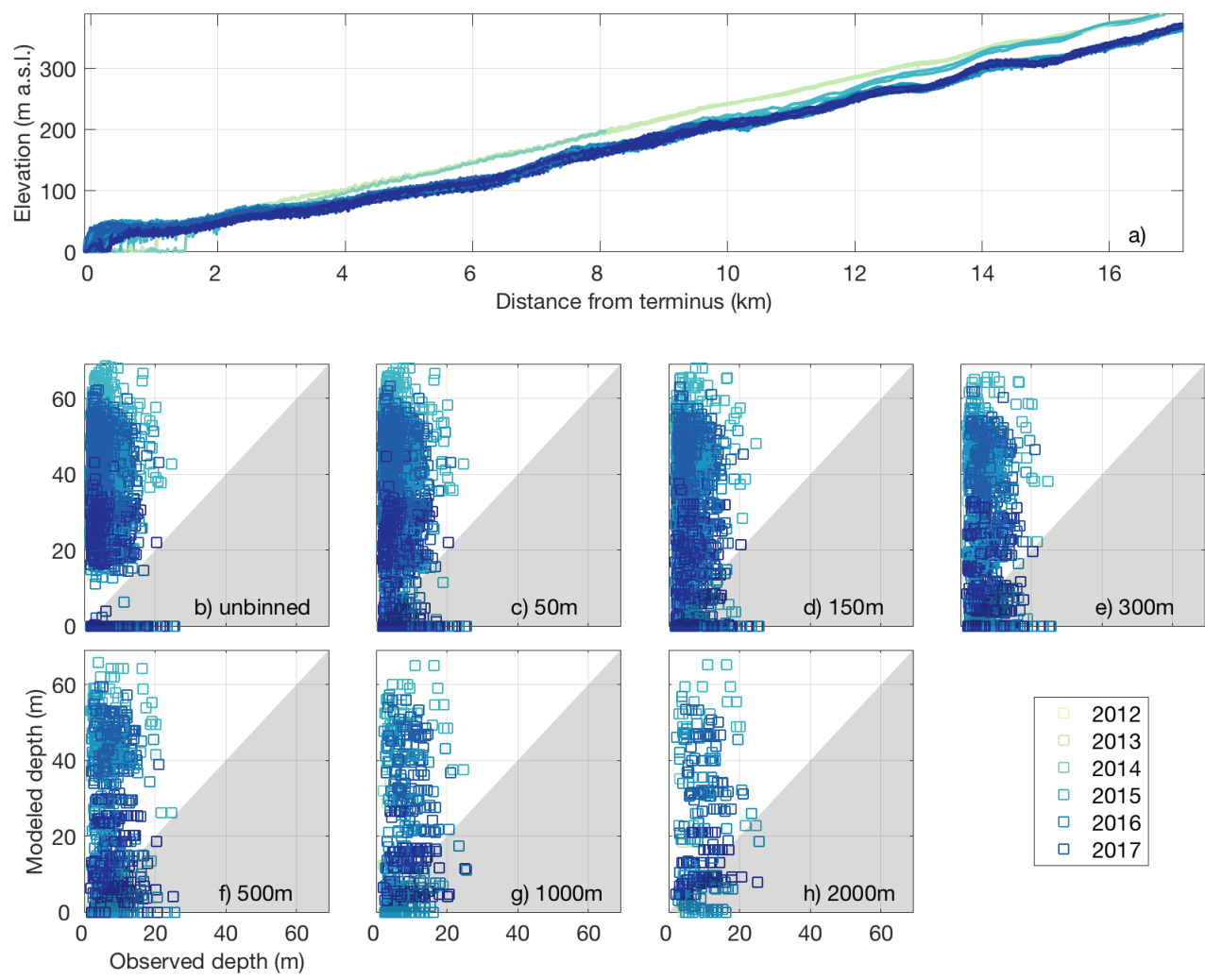

Figure S6: Harald Moltke Bræ (Ullip Sermia) crevasse depth data. The legend indicates the observation year for all panels. a) Elevation profile time series extracted along the Operation IceBridge swath. b-h) Scatterplots of observed crevasse depths plotted against modeled crevasse depths. Points that fall in the white (gray) region represent model over-estimates (underestimates) of the observed depths. All observations are shown in b whereas the maximum observed and median modeled depths within along-flow bins are shown in c-h, with bin sizes ranging from $50-2000 \mathrm{~m}$. 

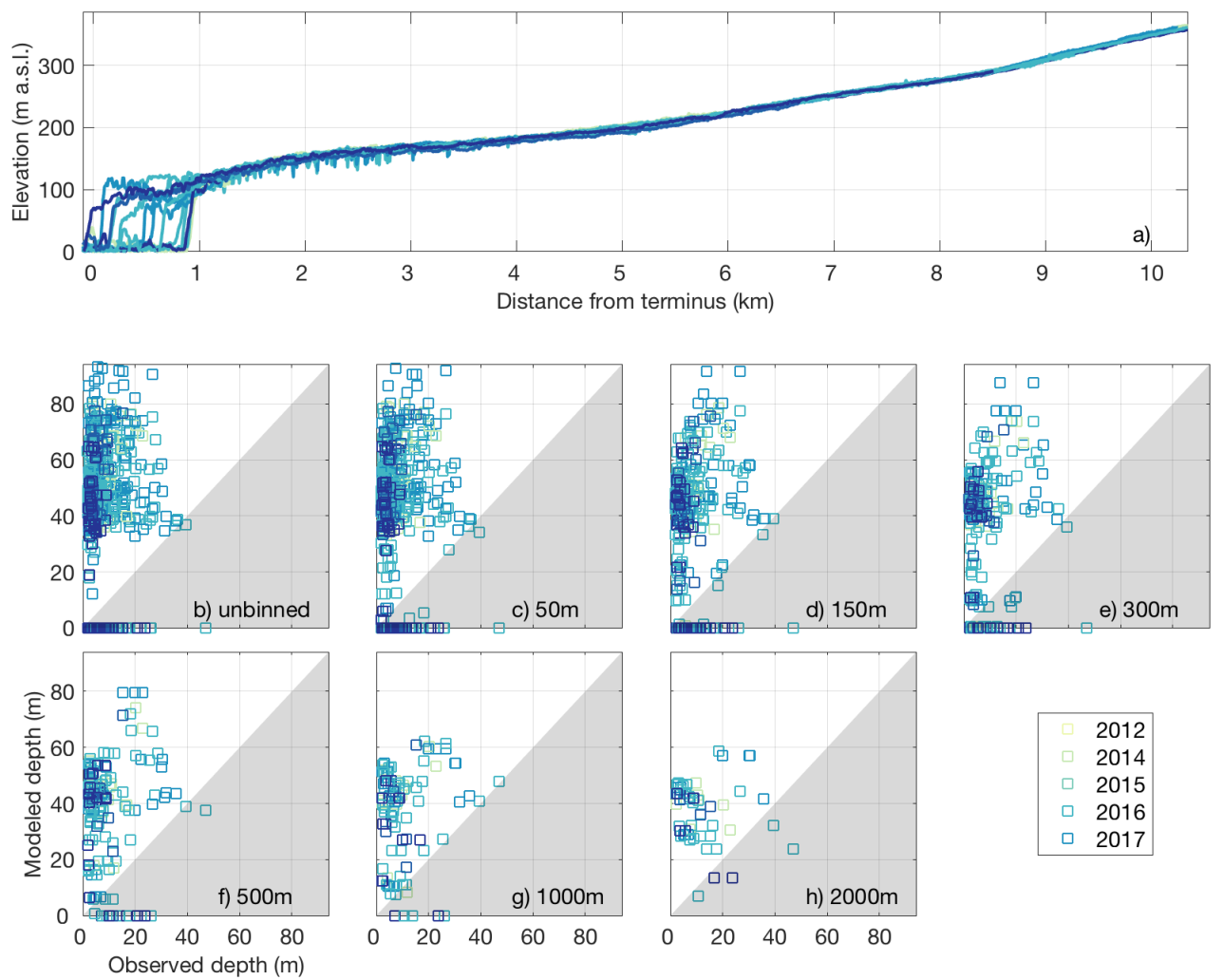

Figure S7: Kong Oscar Gletsjer (Nuussuup Sermia) crevasse depth data. The legend indicates the observation year for all panels. a) Elevation profile time series extracted along the Operation IceBridge swath. b-h) Scatterplots of observed crevasse depths plotted against modeled crevasse depths. Points that fall in the white (gray) region represent model over-estimates (underestimates) of the observed depths. All observations are shown in b whereas the maximum observed and median modeled depths within along-flow bins are shown in c-h, with bin sizes ranging from $50-2000 \mathrm{~m}$. 

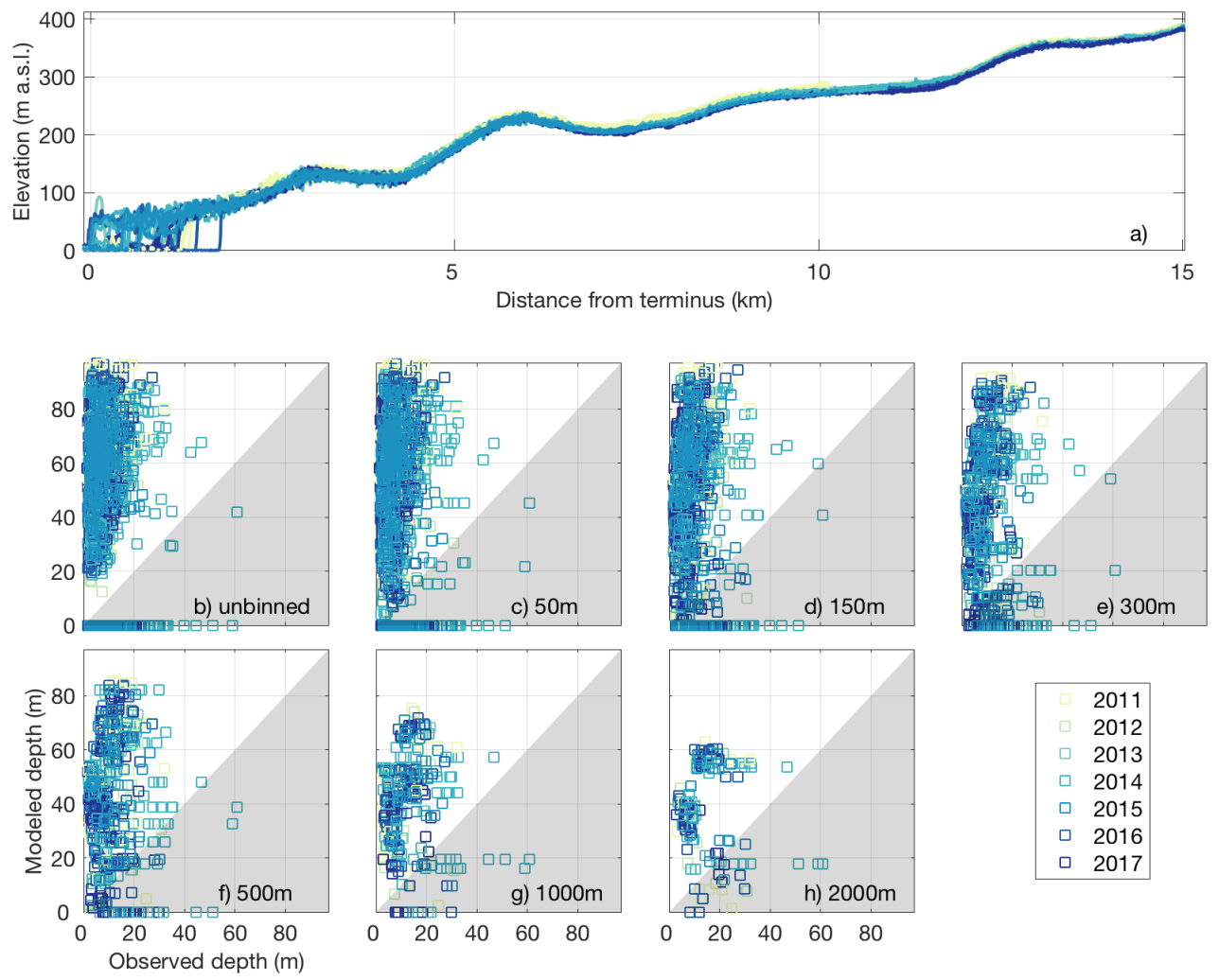

Figure S8: Illullip Sermia crevasse depth data. The legend indicates the observation year for all panels. a) Elevation profile time series extracted along the Operation IceBridge swath. b-h) Scatterplots of observed crevasse depths plotted against modeled crevasse depths. Points that fall in the white (gray) region represent model over-estimates (under-estimates) of the observed depths. All observations are shown in $b$ whereas the maximum observed and median modeled depths within along-flow bins are shown in c-h, with bin sizes ranging from 50-2000m. 

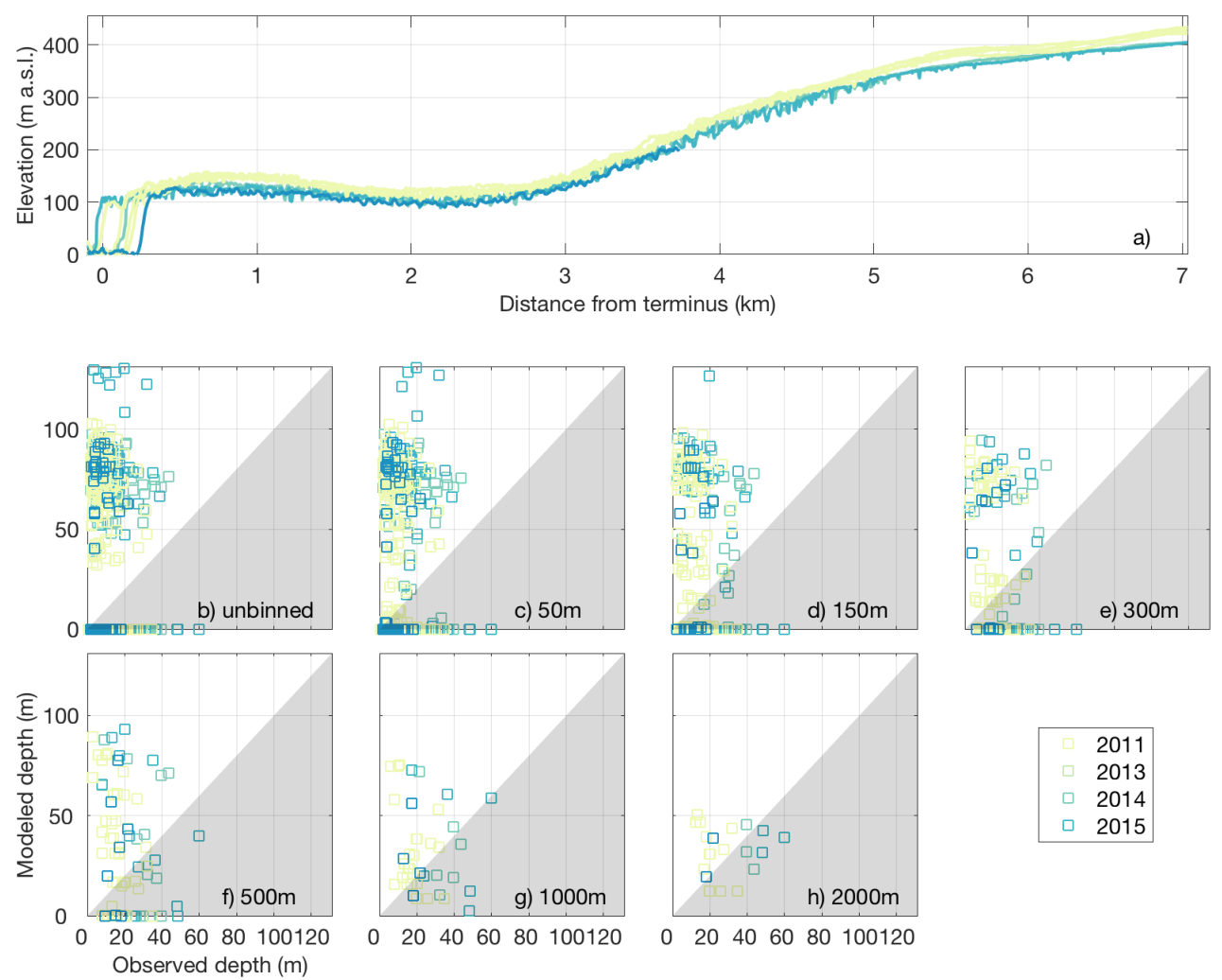

$0 \quad 204060 \quad 80100120$
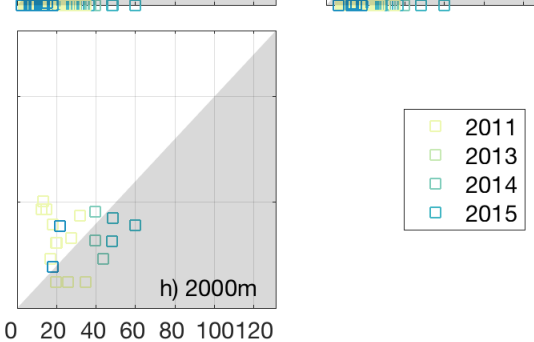

Figure S9: Upernavik North Isstrøm crevasse depth data. The legend indicates the observation year for all panels. a) Elevation profile time series extracted along the Operation IceBridge swath. b-h) Scatterplots of observed crevasse depths plotted against modeled crevasse depths.

5 Points that fall in the white (gray) region represent model over-estimates (under-estimates) of the observed depths. All observations are shown in $b$ whereas the maximum observed and median modeled depths within along-flow bins are shown in c-h, with bin sizes ranging from $50-2000 \mathrm{~m}$. 

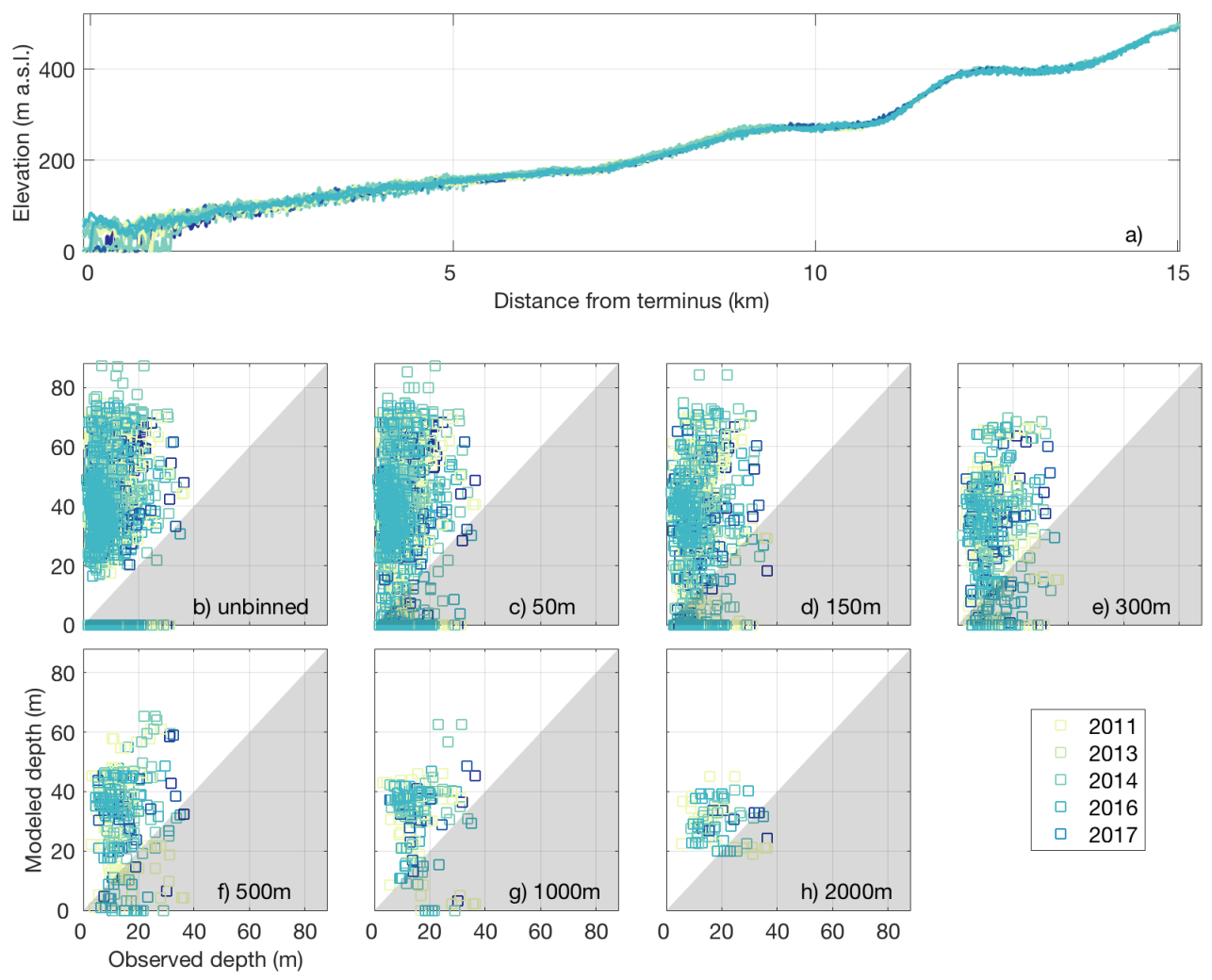

Figure S10: Upernavik Isstrøm (Sermeq) crevasse depth data. The legend indicates the observation year for all panels. a) Elevation profile time series extracted along the Operation IceBridge swath. b-h) Scatterplots of observed crevasse depths plotted against modeled crevasse depths. Points that fall in the white (gray) region represent model over-estimates (underestimates) of the observed depths. All observations are shown in $b$ whereas the maximum observed and median modeled depths within along-flow bins are shown in c-h, with bin sizes ranging from 50-2000m. 

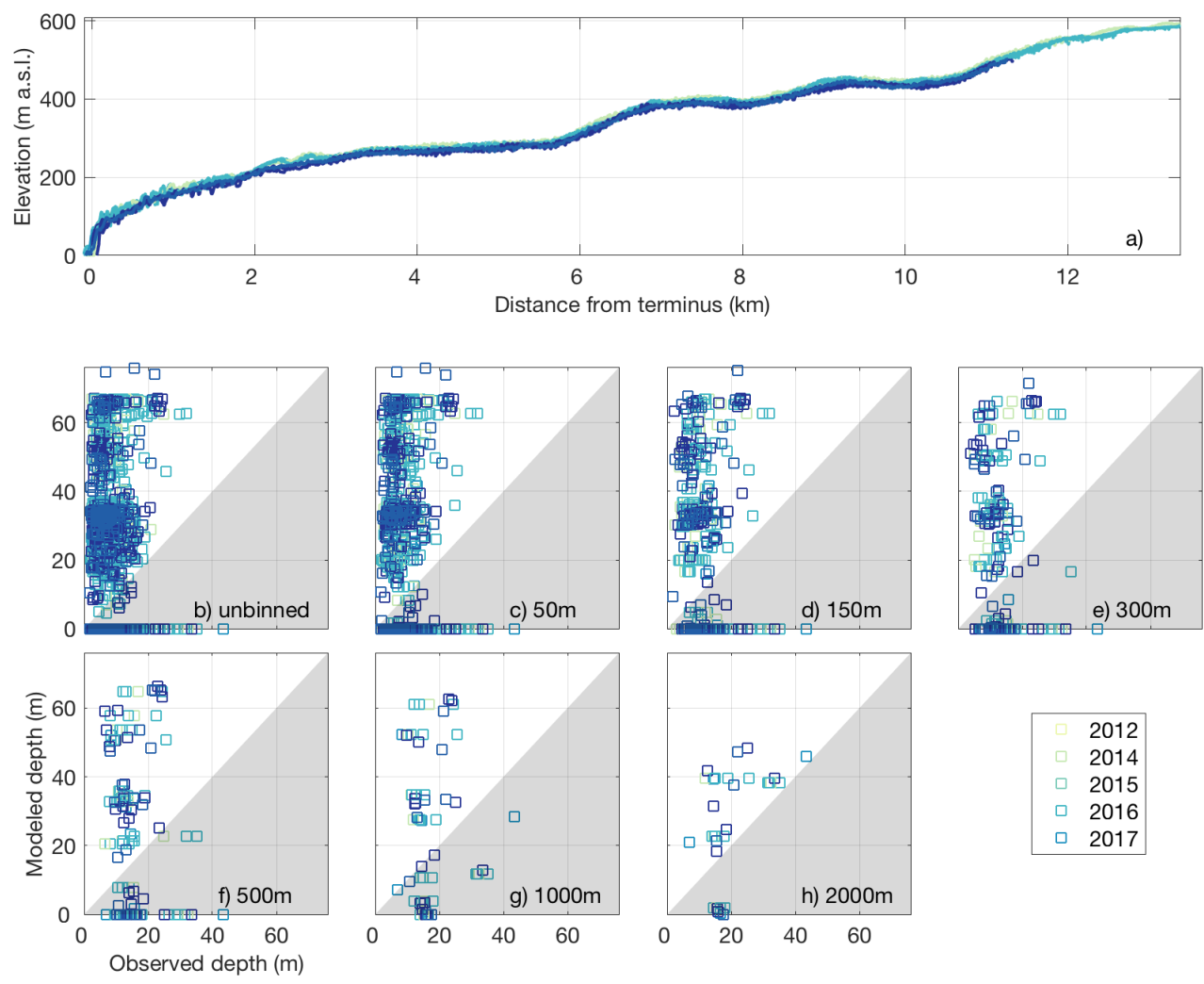

Figure S11: Umiammakku Sermiat crevasse depth data. The legend indicates the observation year for all panels. a) Elevation profile time series extracted along the Operation IceBridge swath. b-h) Scatterplots of observed crevasse depths plotted against modeled crevasse depths.

5 Points that fall in the white (gray) region represent model over-estimates (under-estimates) of the observed depths. All observations are shown in $b$ whereas the maximum observed and median modeled depths within along-flow bins are shown in c-h, with bin sizes ranging from $50-2000 \mathrm{~m}$. 

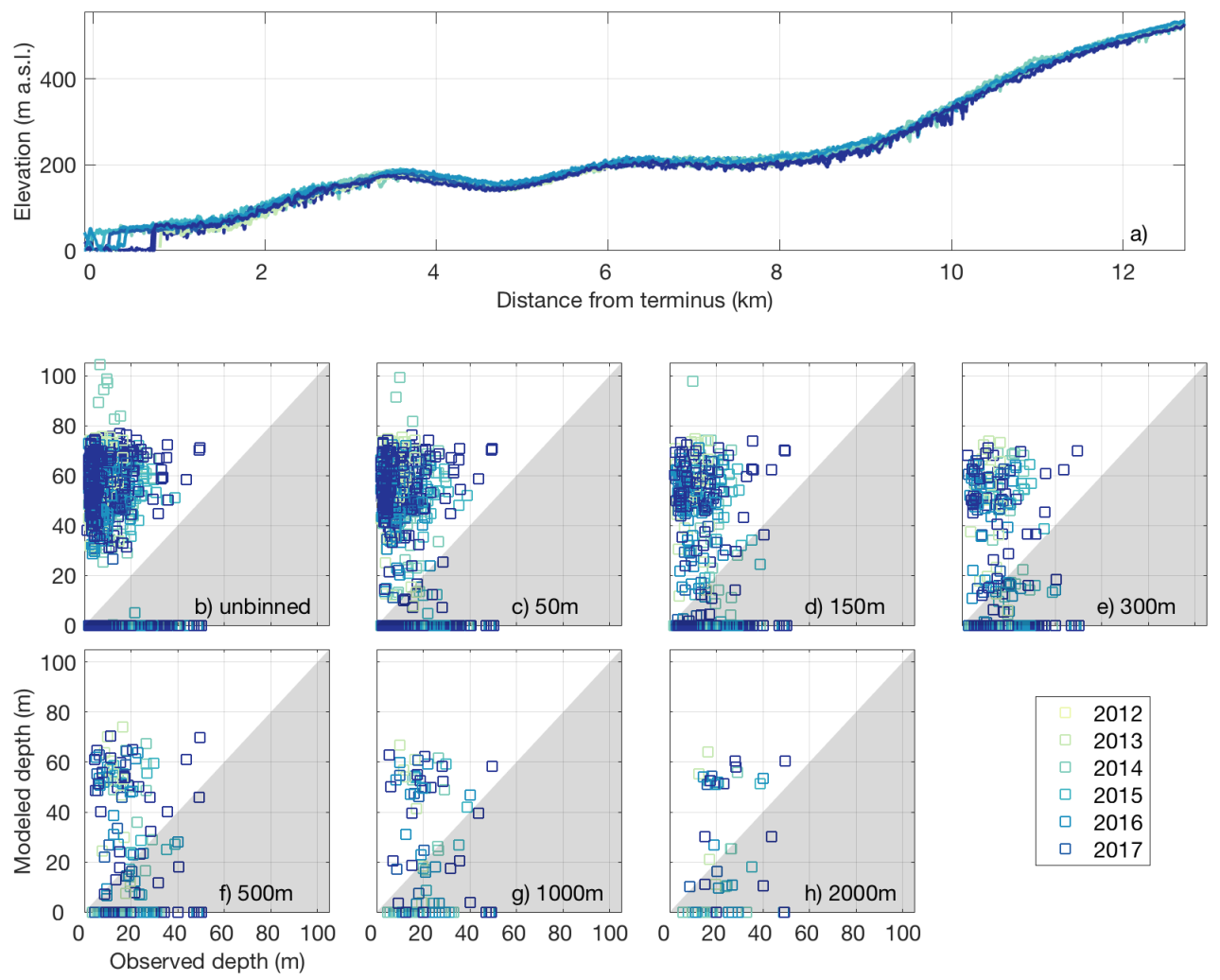

Figure S12: Rink Isbræ (Kangilliup Sermia) crevasse depth data. The legend indicates the observation year for all panels. a) Elevation profile time series extracted along the Operation IceBridge swath. b-h) Scatterplots of observed crevasse depths plotted against modeled crevasse depths. Points that fall in the white (gray) region represent model over-estimates (underestimates) of the observed depths. All observations are shown in b whereas the maximum observed and median modeled depths within along-flow bins are shown in $c-h$, with bin sizes ranging from 50-2000m. 

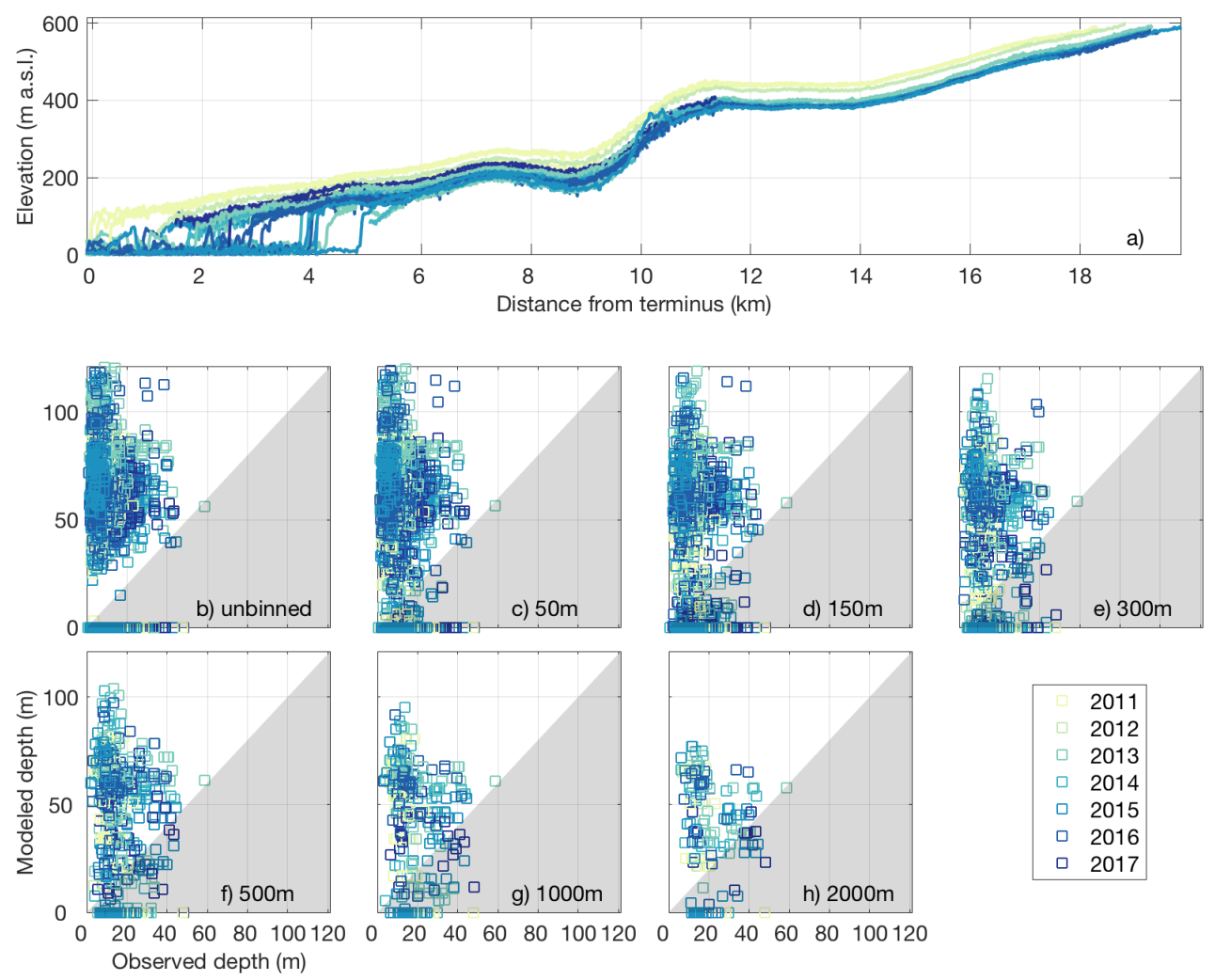

Figure S13: Jakobshavn Isbræ (Sermeq Kujalleq) crevasse depth data. The legend indicates the observation year for all panels. a) Elevation profile time series extracted along the Operation IceBridge swath. b-h) Scatterplots of observed crevasse depths plotted against modeled crevasse depths. Points that fall in the white (gray) region represent model over-estimates (underestimates) of the observed depths. All observations are shown in b whereas the maximum observed and median modeled depths within along-flow bins are shown in c-h, with bin sizes ranging from $50-2000 \mathrm{~m}$. 

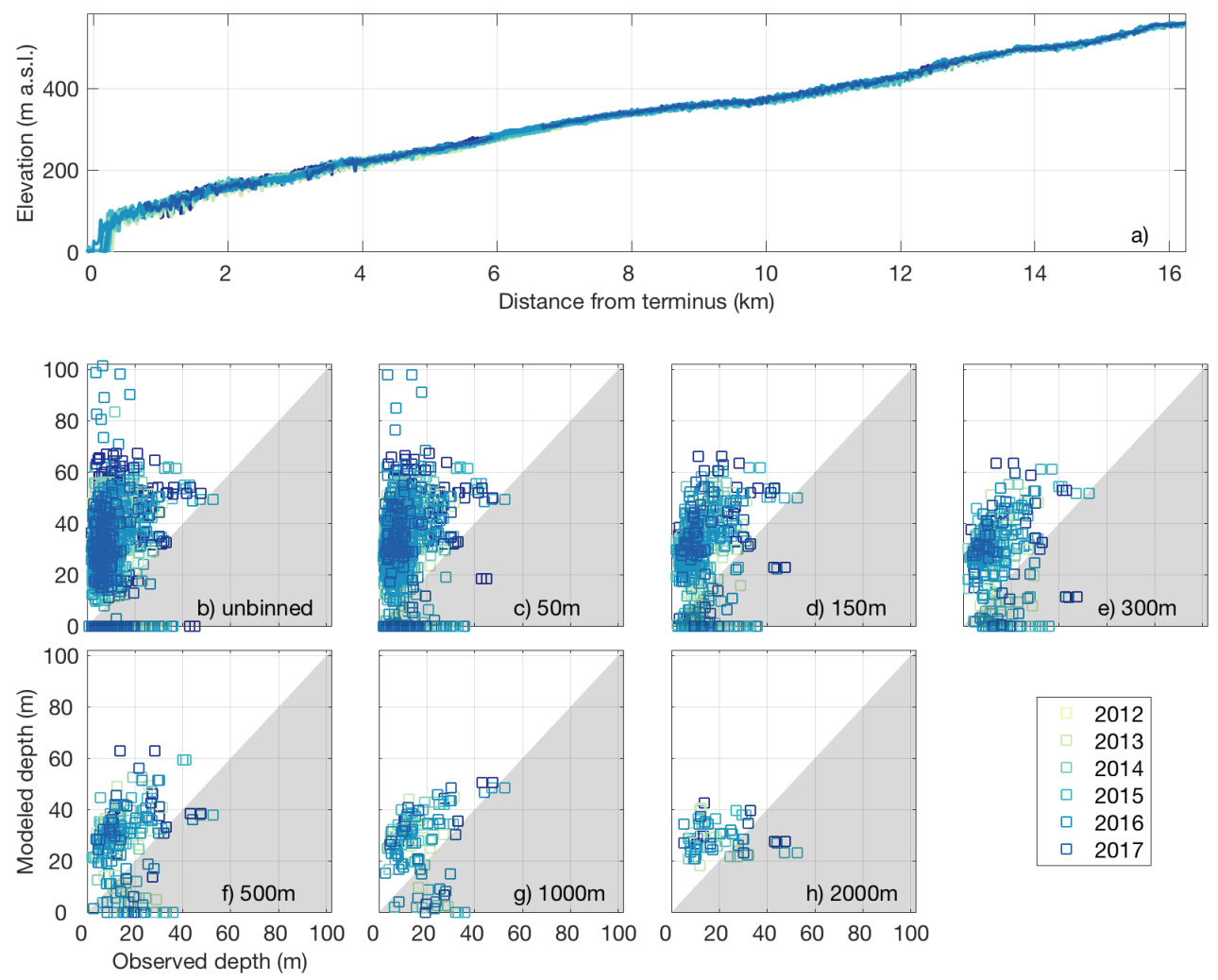

Figure S14: Heimdal Gletsjer crevasse depth data. The legend indicates the observation year for all panels. a) Elevation profile time series extracted along the Operation IceBridge swath. b-h) Scatterplots of observed crevasse depths plotted against modeled crevasse depths. Points that fall in the white (gray) region represent model over-estimates (under-estimates) of the observed depths. All observations are shown in $b$ whereas the maximum observed and median modeled depths within along-flow bins are shown in c-h, with bin sizes ranging from 50-2000m. 

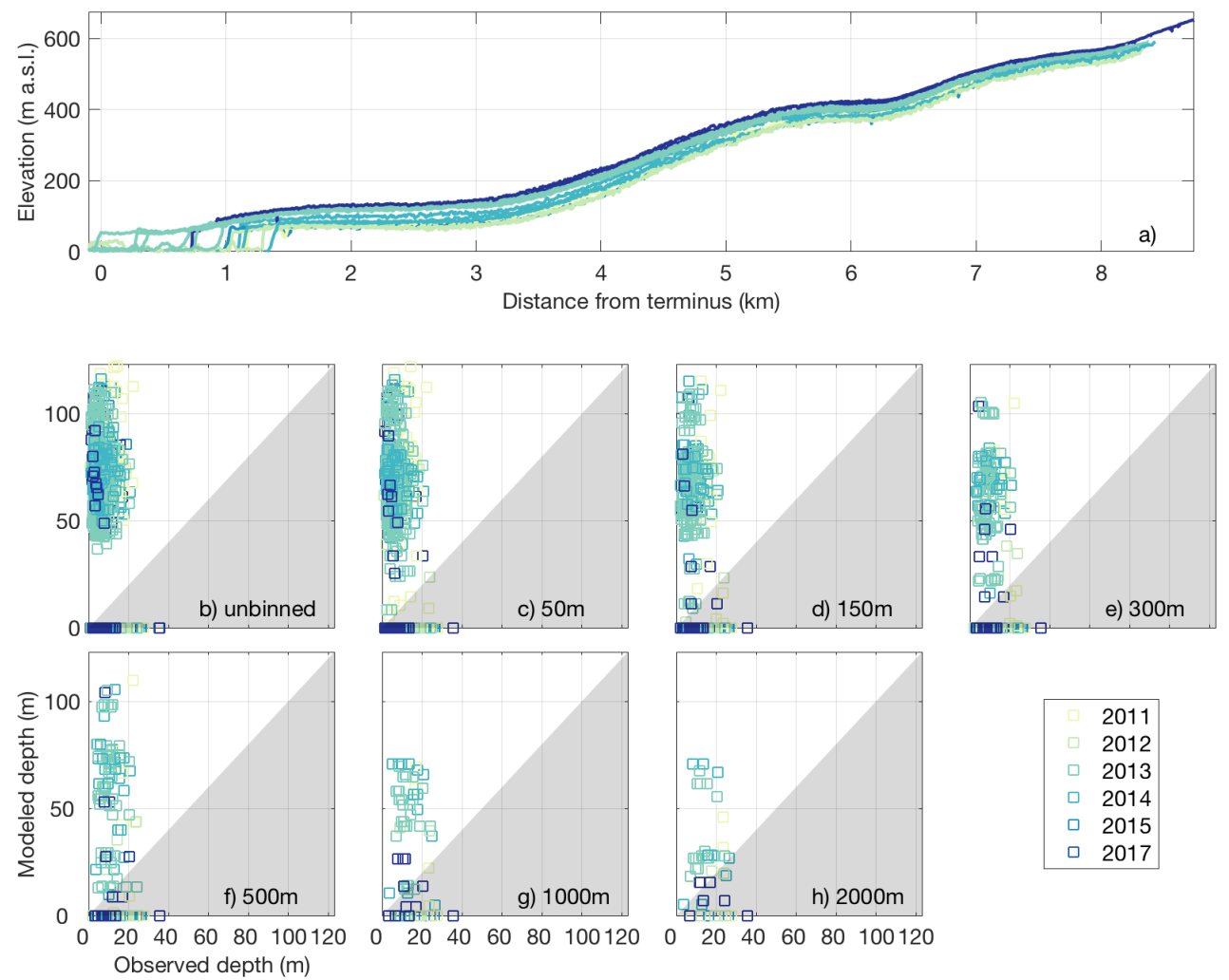

Figure S15: Kogr Bugt Gletsjer crevasse depth data. The legend indicates the observation year for all panels. a) Elevation profile time series extracted along the Operation IceBridge swath. bh) Scatterplots of observed crevasse depths plotted against modeled crevasse depths. Points that fall in the white (gray) region represent model over-estimates (under-estimates) of the observed depths. All observations are shown in b whereas the maximum observed and median modeled depths within along-flow bins are shown in c-h, with bin sizes ranging from 50-2000m. 

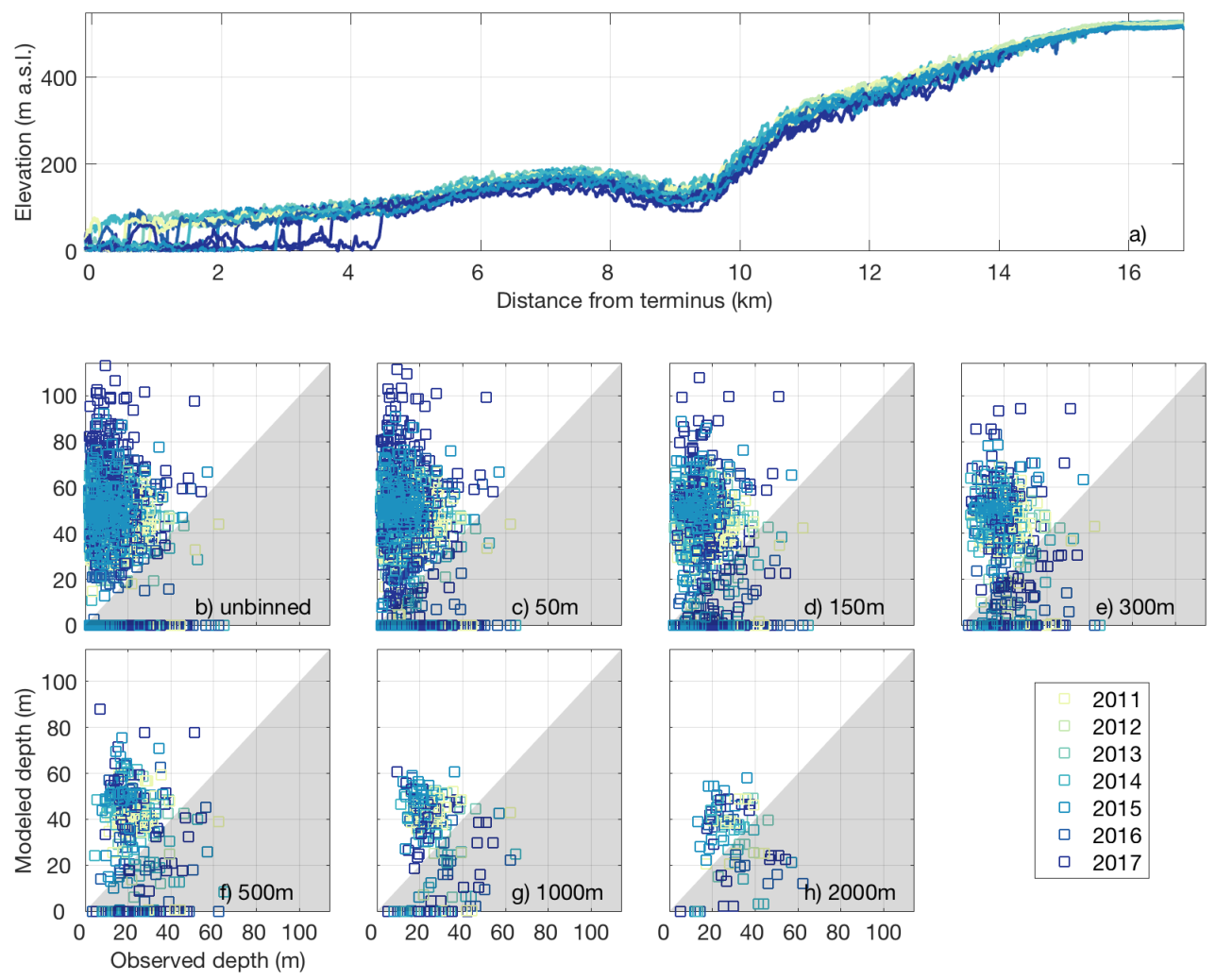

Figure S16: Helheim Gletsjer crevasse depth data. The legend indicates the observation year for all panels. a) Elevation profile time series extracted along the Operation IceBridge swath. b-h) Scatterplots of observed crevasse depths plotted against modeled crevasse depths. Points that fall in the white (gray) region represent model over-estimates (under-estimates) of the observed depths. All observations are shown in $b$ whereas the maximum observed and median modeled depths within along-flow bins are shown in c-h, with bin sizes ranging from 50-2000m. 

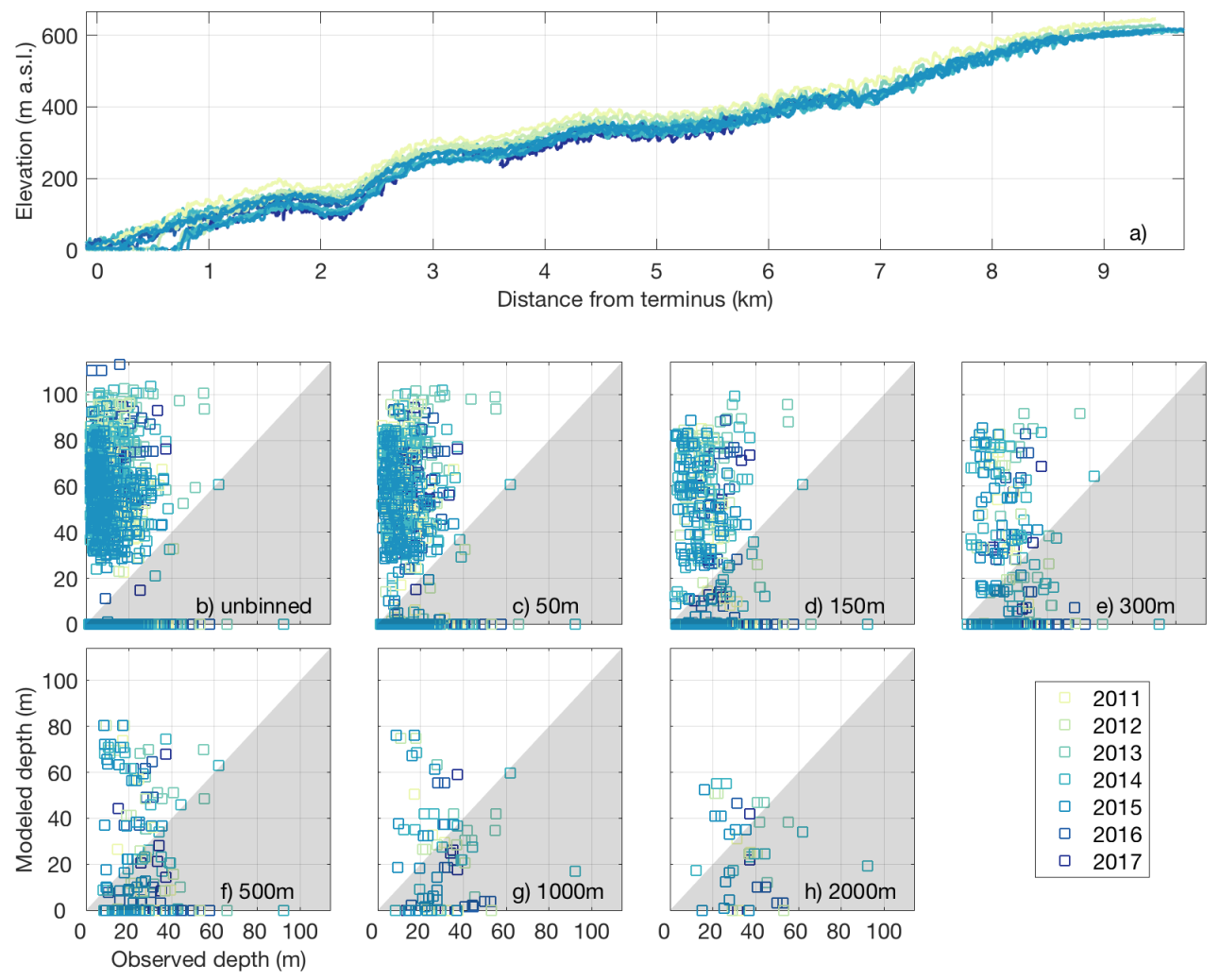
2011
2012
2013
$\square 2014$
2015
$\square 2016$
ㅁ 2017

Figure S17: Midgård Gletsjer crevasse depth data. The legend indicates the observation year for all panels. a) Elevation profile time series extracted along the Operation IceBridge swath. b-h) Scatterplots of observed crevasse depths plotted against modeled crevasse depths. Points that fall in the white (gray) region represent model over-estimates (under-estimates) of the observed depths. All observations are shown in $b$ whereas the maximum observed and median modeled depths within along-flow bins are shown in $\mathrm{c}-\mathrm{h}$, with bin sizes ranging from $50-2000 \mathrm{~m}$. 

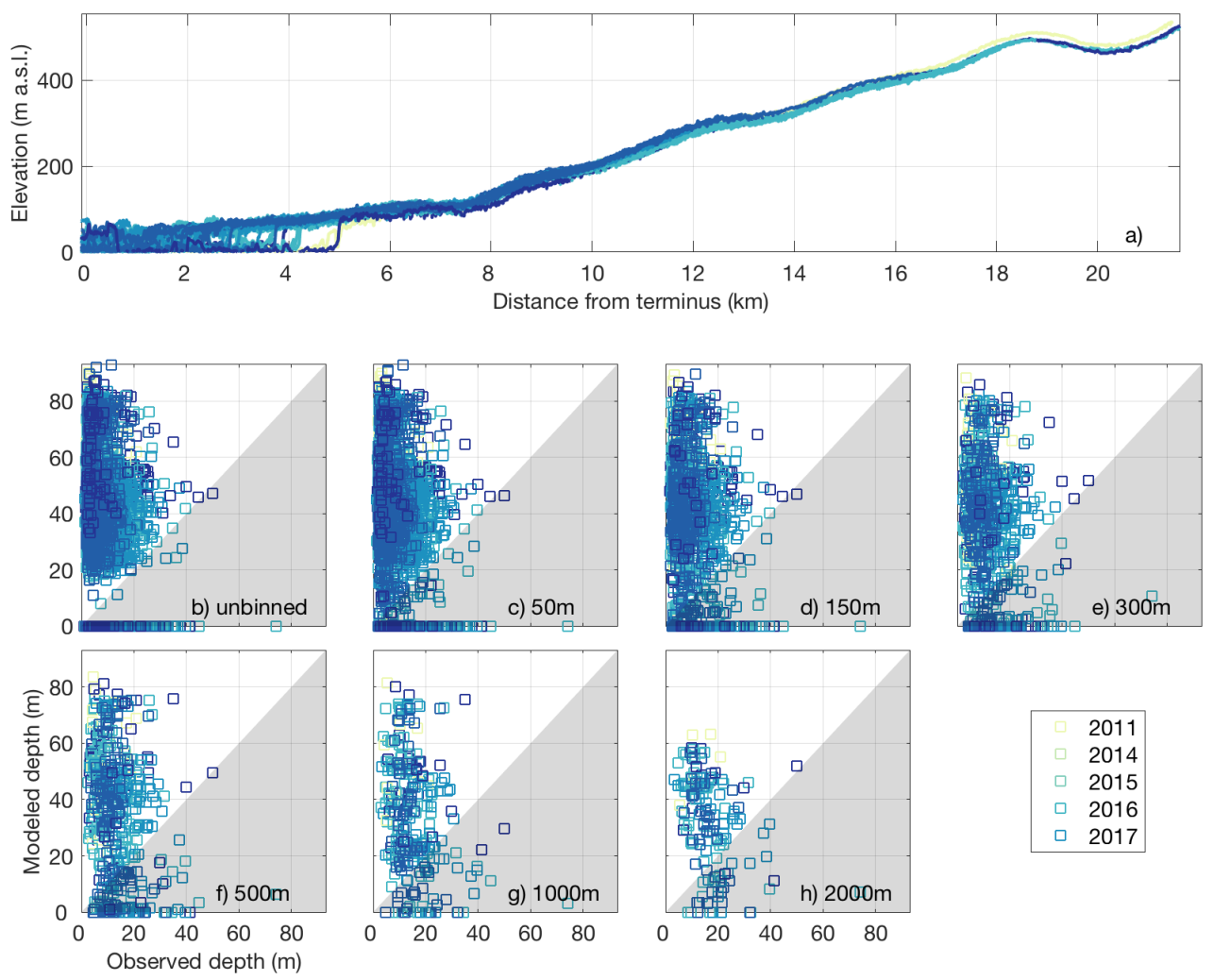

Figure S18: Kangerlussuaq Gletsjer crevasse depth data. The legend indicates the observation year for all panels. a) Elevation profile time series extracted along the Operation IceBridge swath. b-h) Scatterplots of observed crevasse depths plotted against modeled crevasse depths.

5 Points that fall in the white (gray) region represent model over-estimates (under-estimates) of the observed depths. All observations are shown in $b$ whereas the maximum observed and median modeled depths within along-flow bins are shown in $\mathrm{c}-\mathrm{h}$, with bin sizes ranging from $\mathbf{5 0 - 2 0 0 0 m}$. 

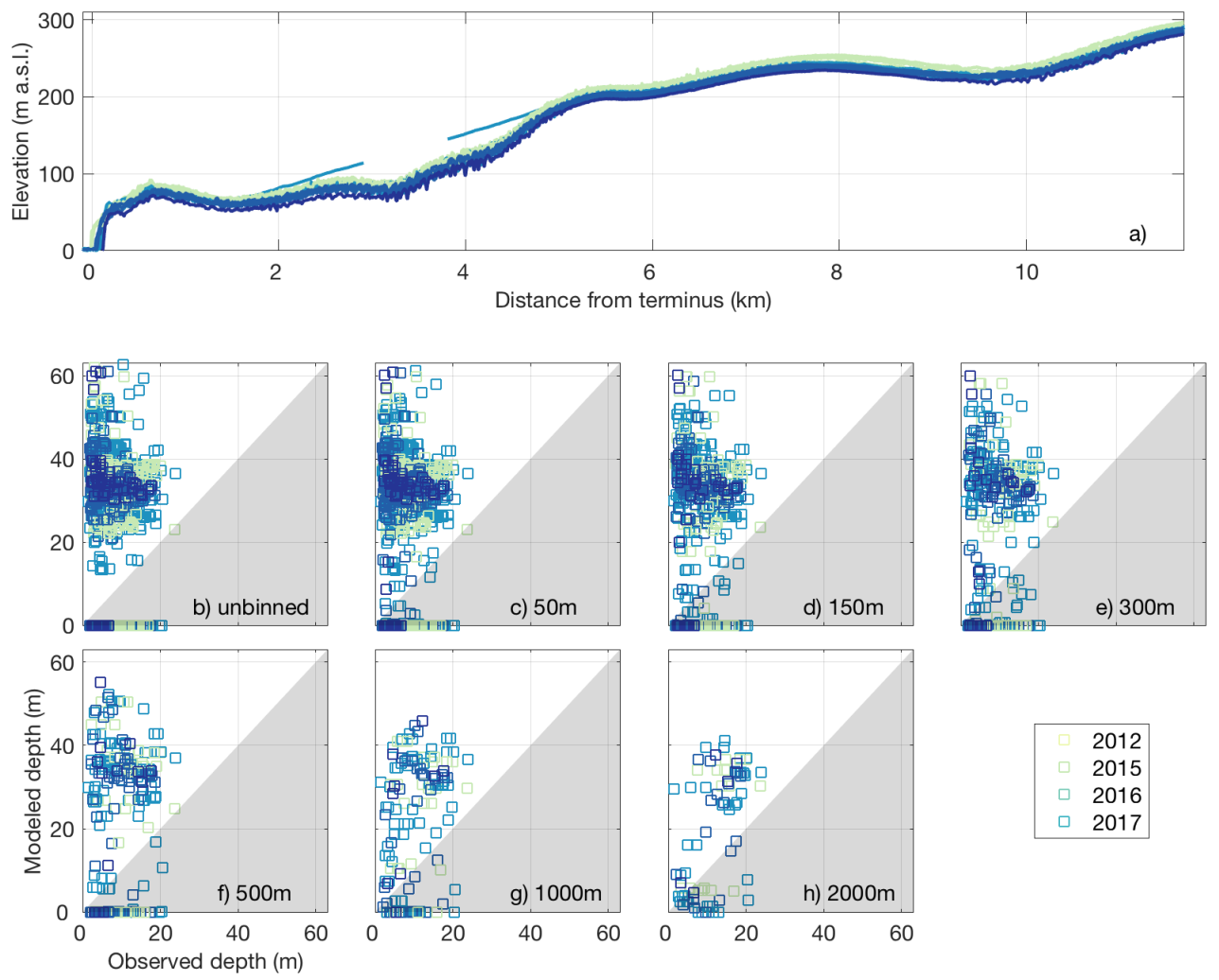

Figure S19: Dendrit Gletsjer crevasse depth data. The legend indicates the observation year for all panels. a) Elevation profile time series extracted along the Operation IceBridge swath. b-h) Scatterplots of observed crevasse depths plotted against modeled crevasse depths. Points that fall in the white (gray) region represent model over-estimates (under-estimates) of the observed depths. All observations are shown in $b$ whereas the maximum observed and median modeled depths within along-flow bins are shown in c-h, with bin sizes ranging from 50-2000m. 

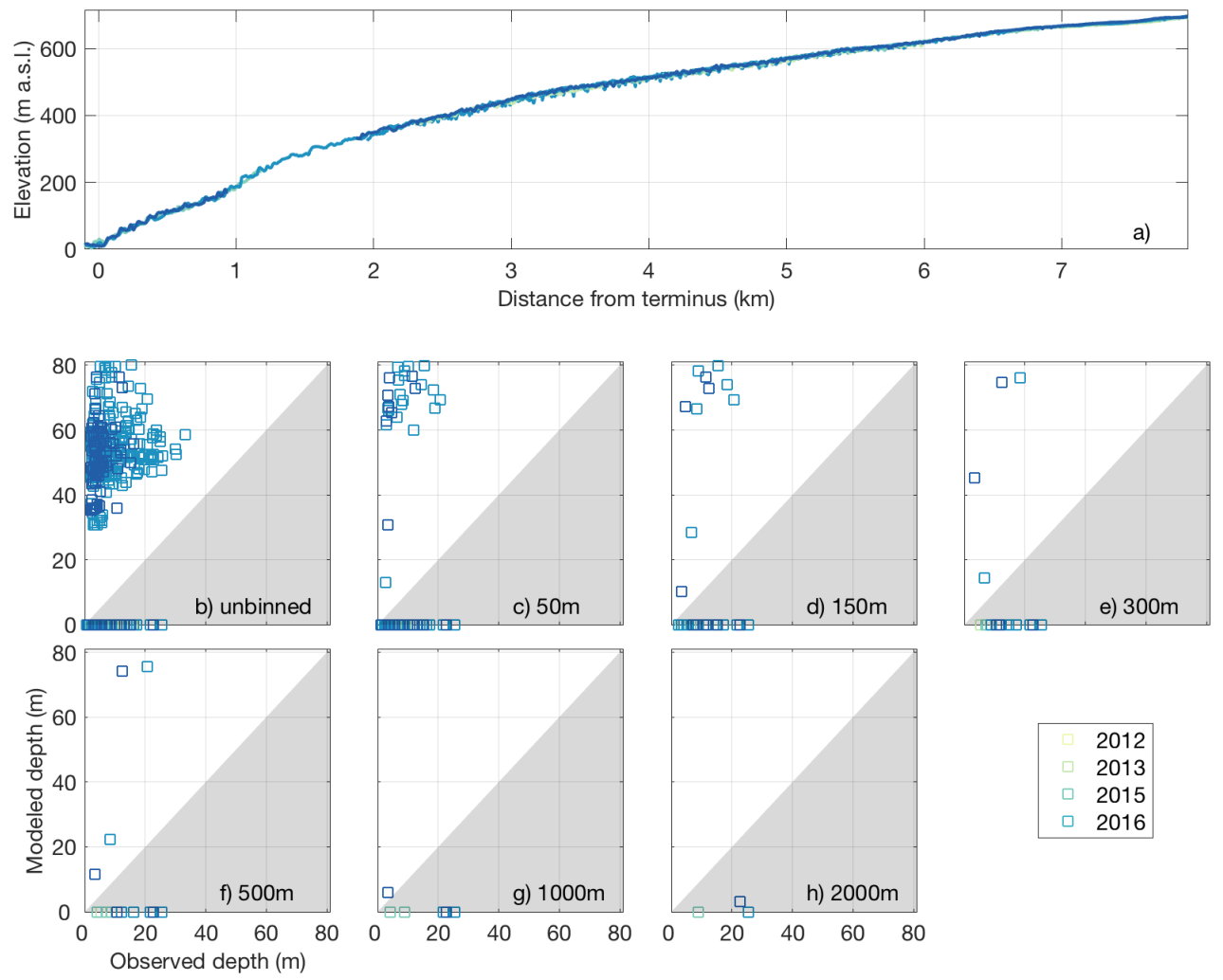

Figure S20: Magga Dan Gletsjer crevasse depth data. The legend indicates the observation year for all panels. a) Elevation profile time series extracted along the Operation IceBridge swath. bh) Scatterplots of observed crevasse depths plotted against modeled crevasse depths. Points that fall in the white (gray) region represent model over-estimates (under-estimates) of the observed depths. All observations are shown in $b$ whereas the maximum observed and median modeled depths within along-flow bins are shown in c-h, with bin sizes ranging from $50-2000 \mathrm{~m}$. 

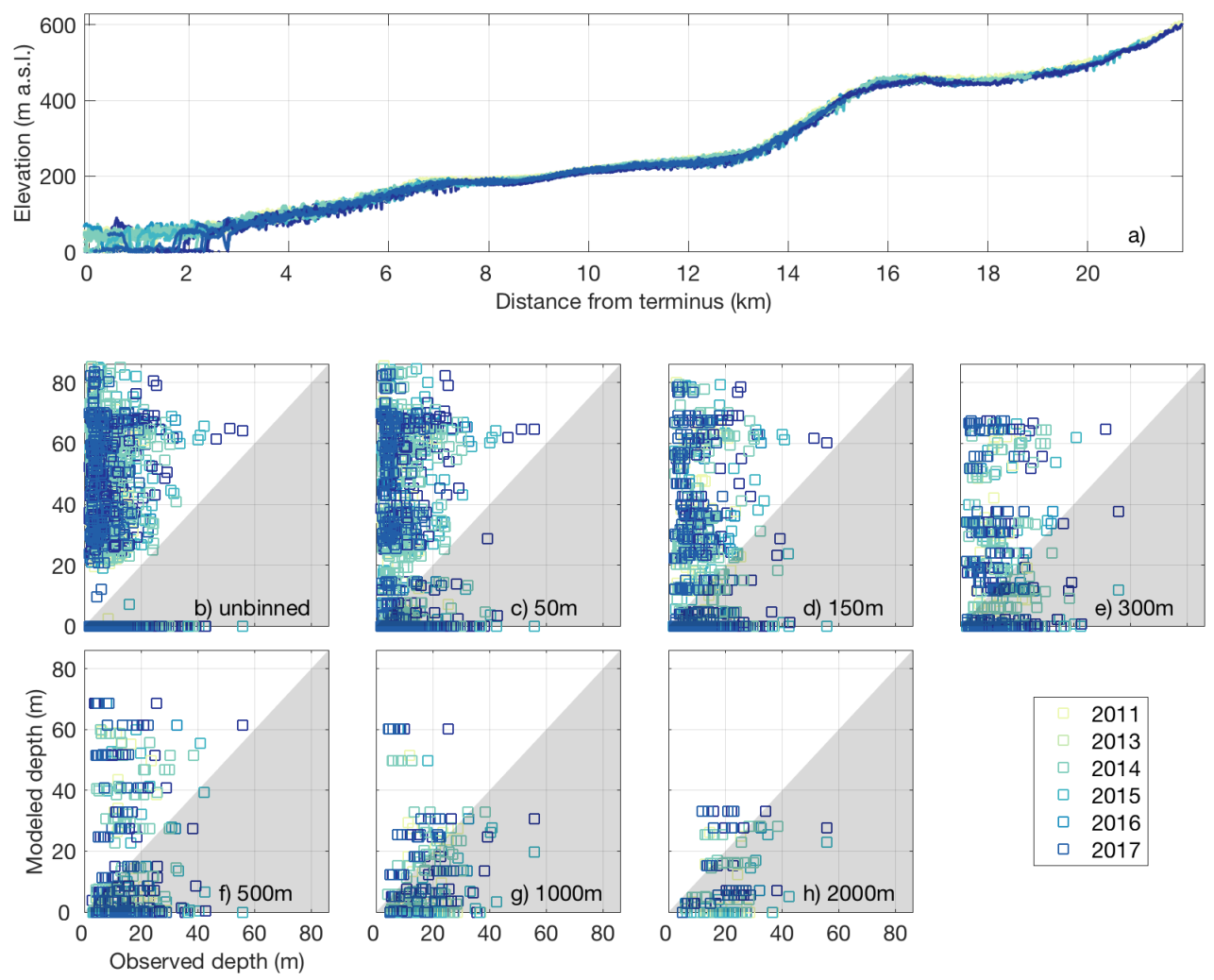

Figure S21: Daugaard Jensen Gletsjer crevasse depth data. The legend indicates the observation year for all panels. a) Elevation profile time series extracted along the Operation IceBridge swath. b-h) Scatterplots of observed crevasse depths plotted against modeled crevasse depths.

5 Points that fall in the white (gray) region represent model over-estimates (under-estimates) of the observed depths. All observations are shown in $b$ whereas the maximum observed and median modeled depths within along-flow bins are shown in c-h, with bin sizes ranging from $50-2000 \mathrm{~m}$. 

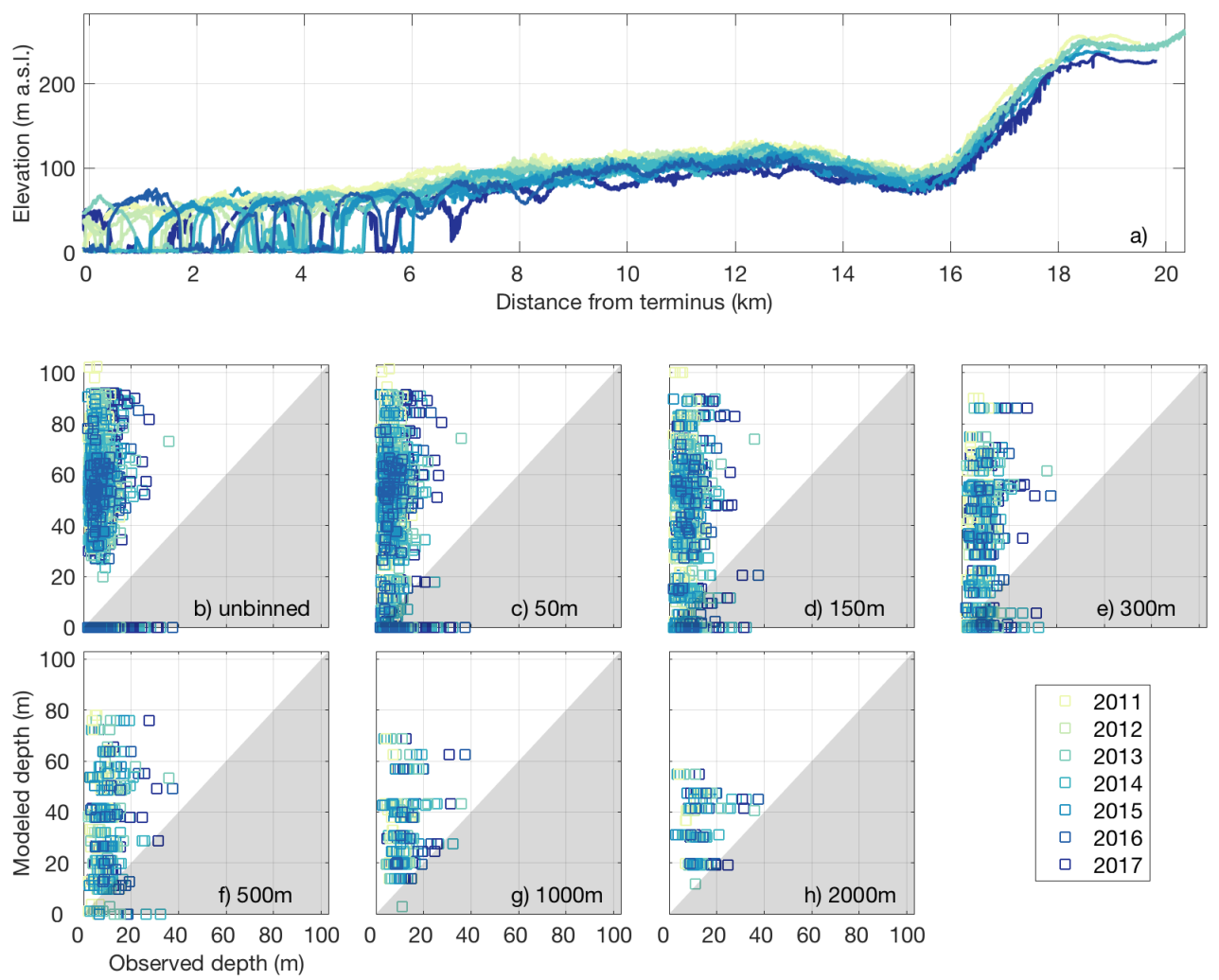

Figure S22: Zachariae Isstrøm crevasse depth data. The legend indicates the observation year for all panels. a) Elevation profile time series extracted along the Operation IceBridge swath. b-h) Scatterplots of observed crevasse depths plotted against modeled crevasse depths. Points that fall in the white (gray) region represent model over-estimates (under-estimates) of the observed depths. All observations are shown in $b$ whereas the maximum observed and median modeled depths within along-flow bins are shown in c-h, with bin sizes ranging from $50-2000 \mathrm{~m}$. 


— observed $\longrightarrow$ modeled: minimal — modeled: $\epsilon_{\text {crit }}>0$ modeled: enhanced flow
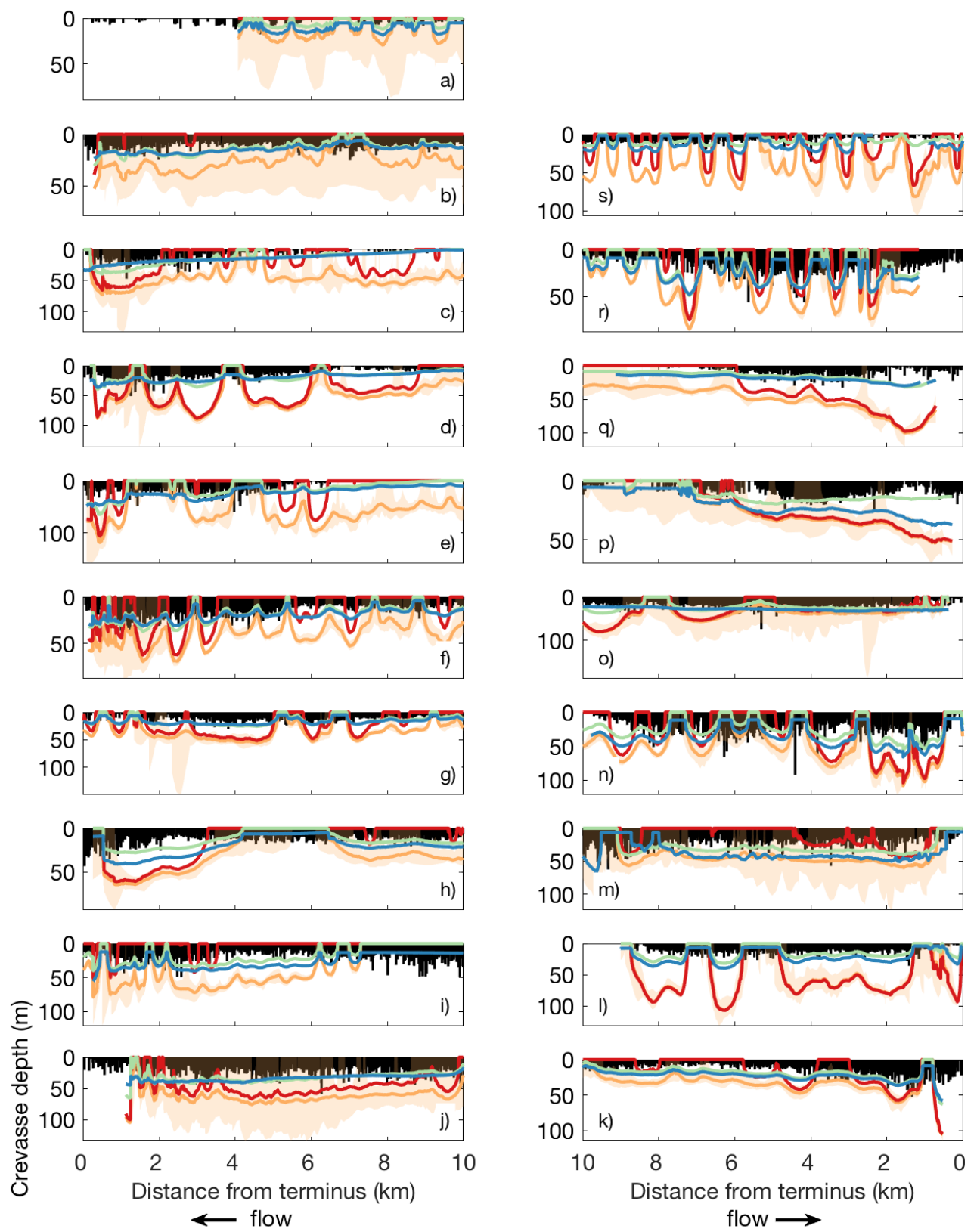

Figure S23: Crevasse depth profiles over the seaward-most $10 \mathrm{~km}$ of each glacier. Observed crevasse depths are in black. Modeled depths using the minimal (orange), non-zero strain rate threshold (red), parameterized flow enhancement (green), and parameterized water depth (blue) 
versions of the Nye formulation for crevasse depth are plotted using the median strain rate profile. Temporal variability in the crevasse depths from the minimal model are shown as orange shading. Panels are organized geographically, as in Figure S2. 


\section{Tables}

\begin{tabular}{|c|c|c|c|}
\hline & \multicolumn{2}{|c|}{ search window widths $(m)$} \\
\hline & & $30,60,90$ & $45,90,135$ \\
\hline \multirow{6}{*}{ 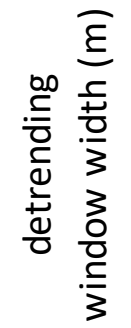 } & 350 & $350 ; 30,60,90$ & $350 ; 45,90,135$ \\
\hline & 450 & $450 ; 30,60,90$ & $450 ; 45,90,135$ \\
\hline & 500 & $500 ; 30,60,90$ & $500 ; 45,90,135$ \\
\hline & 550 & $550 ; 30,60,90$ & $550 ; 45,90,135$ \\
\hline & 650 & $650 ; 30,60,90$ & $650 ; 45,90,135$ \\
\hline & 800 & $800 ; 30,60,90$ & $800 ; 45,90,135$ \\
\hline
\end{tabular}

Table S1: Window sizes for automated crevasse identification. 